\title{
Olaf Flak $^{*}$
}

\section{SELECTED PROBLEMS IN TEAM MANAGEMENT AUTOMATION}

\begin{abstract}
A b s t r a c t: The contradiction between the unstable nature of team work and the opportunity coming from IT technologies creates a question how to replace a human manager with a robot. Therefore the paper presents selected problems in in achieving the answer such as what are dominating methodological problems in management science, how to represent manager work, what research method should be used, what research tools should be used and what methods of reasoning should be used. Some of the problems have been solved by the author and some still wait for efficient solutions.
\end{abstract}

K e y w o r d s: research methodology in management science, the system of organizational terms, research methods, research tools, online management tools, team management automation

K 1 a s y fik a c j J E L: L 21

\section{INTRODUCTION}

Due to their ability to respond more effectively to the dynamic and complex environments faced by the organizations today, work teams have become more and more relevant in the past decades [Mathieu, Maynard, Rapp \& Gilson, 2008]. On the one hand, team work contains actions with which team managers they need to be able to identify, articulate and respond to the unexpected contingencies. These actions lead to the consequences which managers are not able to foresee [Segal, 2011, p. 472]. On another hand, after the first age of robotics in mechanical processes and manufacturing rapid development of computer science and Internet gives opportunities to replace team managers with robots [McAfee, Goldbloom, Brynjolfsson \& Howard, 2014]. This would be the real accomplishment of the Drucker's words that in the future "computers" will not only make decisions but they will do much more [Drucker, 1967].

\footnotetext{
* Adres do korespondencji: Olaf Flak, Uniwersytet Śląski w Katowicach, Wydział Radia i Telewizji im. K. Kieślowskiego, ul. Bytkowska 1b, 40-147 Katowice, e-mail: olaf.flak@us.edu.pl;
} 
The contradiction between the unstable nature of team work and the opportunity coming from IT technologies creates a question if it is possible to replace a human manager with a robot. However, from implementation point of view there comes another question which should be answered before implementing team management automations. The question is: what does a team manager really make? [Sinar \& Paese, 2016, p. 46]

Therefore the aim of this paper is to present selected problems in a way to achieving an answer to this question. Some of the problems have been already solved, however, some are still not fully described methodological or practical dilemmas. These problems can be represented by such research questions:

- What are dominating methodological problems in management science?

- How to represent manager work?

- What research method should be used?

- What research tools should be used?

- What methods of reasoning should be used?

In the next Sections those problems are described in two ways. Firstly, these problems which have been already answered and verified, are presented in the perspective of related work and proposed solutions. Secondly, these problems which did not occur in the literature have their own prototypical solutions.

\section{METHODOLOGICAL PROBLEMS IN MANAGEMENT SCIENCE}

During last decades a vivid discussion about several methodological problems in the management science was seen in the literature and in scientific society. Such problems concern H. Koonst's „theory jungle” [1961], large subjectivity in theories [Hicks \& Goronzy, 1967, p. 383], „overproduction of the truth" [Darmer, 2000], chaos in definitions and scientific language [Hodge, 2003, p. 242], building ,islands of knowledge" instead of developing a stable model of reality [Gleiser, 2014]. There are also the domination of the study of organizational reality based on the situation at certain times, leading to a static and momentary evaluation of the reality [Rokita, 2010], too much influence of the subjectivity of the theorists on the theory in the management sciences [Sudot 2010 , p. 6], the disproportionate nature of the whole scientific discipline, especially in terms of methods of conducting research and interpretation of their results [Sułkowski 2004, p. 6].

These problems cause that building knowledge on the organizational reality and particularly on team management still encounters a lot of obstacles. A lack of coherent and scalable empirical foundations of team managers' and team members' behaviour do not let implement automation in this area.

The attempt of solving these methodological problems is the system of organizational terms, which is a complex of ontological and epistemological aspects 
designed for managerial action patterns research [Flak, 2007; Flak, 2008, Flak, 2009, Flak, 2010; Flak, 2013c].

The ontological assumption of the system of organizational terms is that every fact in the organizational reality can be represented by the organizational term [Zalabardo, 2015]. The organizational term is a symbolic object which can be used as an element of the organizational reality model [Rios, 2013]. The organizational term is a close analogy to a physical quantity in the SI unit [length, mass, time etc.]. The philosophical foundation of the system of organizational terms is based on Wittgenstein's philosophy: his theory of facts [the only beings in the world] and "states of facts" [Brink \& Rewitzky, 2002]. According to this approach the organizational reality can be organised by events and things. Specifically, as shown in Figure 1, each event and each thing have the label n.m, in which $n$ and $m$ represent a number and a version of a thing, respectively. Event 1.1 causes thing 1.1, which in turn releases event 2.1 that creates thing 2.1. Thing 1.1 simultaneously starts event 3.1 which creates thing 3.1 . Then, thing 3.1 generates a new version of the first event, i.e. event 1.2. In such a way, a new version of the first thing is created, which is called thing 1.2.

Figure 1. Fundamental structure of organizational reality

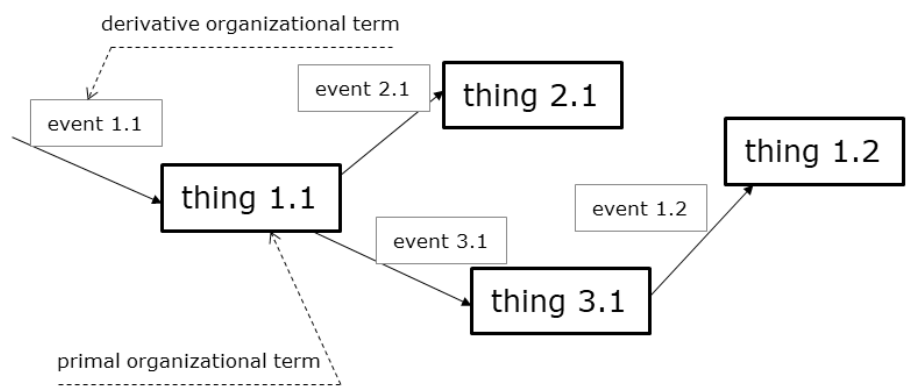

Source: Own elaboration

According to the logical division, organizational terms are divided into two classes: primal and derivative organizational terms. Facts, which are things [primal organizational terms] in the organizational reality, represent resources [Barney, 1991]. Facts, which are events (derivative organizational terms) in the organizational reality, represent processes in the organization [Brajer-Marczak, 2016]. By the same token, the system of organizational terms combines the resource approach and the process approach in the management science. It combines processes which effect in resources. 


\section{MANAGER WORK REPRESENTATION}

It seems there are three dominating representations of manager work in literature which appeared chronologically during the last 50 decades. Firstly, many papers mentioned manager work in terms of management styles. It is necessary to present 3 main classical approaches to management styles. There is the Tannenbaum-Schmiet Management Model oriented towards tasks [results] and people (relationships) [Tannenbaum \& Schmidt, 1958]. Management styles according to this model are: authoritarianism, elitism, consultation, democracy. There is also Blake and Mouton Management Grid based on the two indicators of concern for people and concern of results. In this division we distinguish five classes of management styles: impoverished management, authoritarian management, relationship oriented management, balanced management, integrated management [Blake \& Mouton, 1965]. Finally, there is Likert's management system proposing four different types of management style: exploitive-authoritative, benevolent authoritative, consultative, participative [Likert, 1958].

Secondly, manager work can be described by managerial skills. Managerial skills [in classic approach: technical, interpersonal and conceptual] are defined as abilities to work effectively as a team manager and to build cooperative effort within the team which the manager leads [Katz, 1974]. Thirdly, managerial roles were introduced in order to describe manager work. They are defined as areas of job activities which are undertaken by a manager, e.g. figurehead, leader, liaison, monitor, disseminator, spokesman, entrepreneur, disturbance handler, resource allocator, negotiator [Mintzberg, 1980].

These three dominating approaches were developed during past decades and used for a lot of field research projects. However, their main disadvantages are still the same: they do not recognize what a team manager really makes and there is a lack of stable knowledge on team managers which would be apart from subjectivity of researchers and research participants.

The solution to these problems is hidden in the relation between managerial roles and managerial skills, because it is said, in order for a manager to play managerial roles, they should have some managerial skills [Pavett \& Lau, 1983]. Playing managerial roles within their managerial skills by day-today activities of managers effects in the managerial actions, which these managers make. Therefore, the managerial action can be an effective representation of manager work. The managerial action is defined as a real activity, which a manager does in order to play a managerial role when he has a certain managerial skill.

In the perspective of the structure of organizational reality, presented in Figure 1, the managerial action structure consist of, e.g. event 1.1 and thing 1.1. Event 1.1 can be in the team management a process set 1.1 which results in Thing 
1.1 - goal 1.1. In this pair they create the managerial action [Figure 2]. This concept lets us represent manager work by activities taken by managers.

Figure 2. Fundamental structure of managerial actions

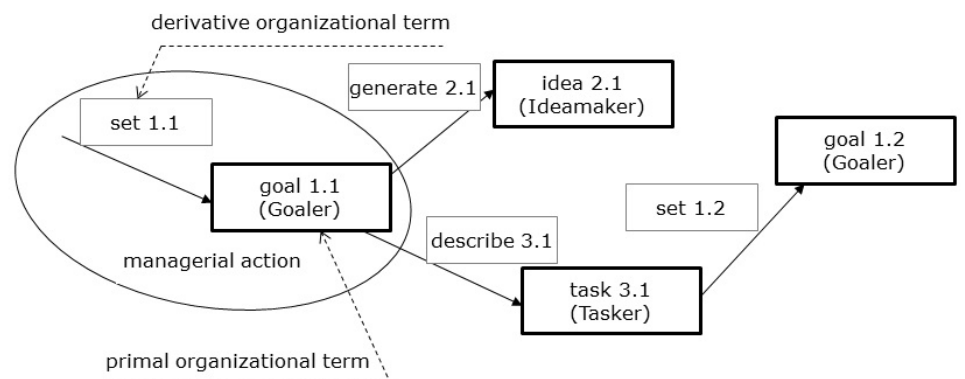

Source: Own elaboration

Despite the fact that on the abstract level this is a clear and universal approach, the next emerging problem concerns a method of measuring certain managerial actions.

\section{RESEARCH METHOD}

From the point of view of research methods used to examine manager work, there are three general types of these methods. Firstly, qualitative and quantitative approaches. Secondly, experimental methods [Spector \& Meier, 2014]. Thirdly, nonexperimental methods - archival designs, direct observation, panel designs, retrospective event history, daily diary studies, sequence analysis [Herauf, 2006]. However, none of these methods gives highly precise and quantitative results because of a lack of appropriate research tools which could track managerial actions in precise and detailed way.

Much more efficient it seems to take into consideration a group of observation methods. The first work observations were made by F. and L. Gilbreth at the beginning of 20th century [Karsten, 1996]. They investigated human motions at work, which was the beginning of workforce automation in many industries [Spriegel \& Myers, 1953]. Later in the literature there can be found an approach to research called time motion study [Barnes, 1980]. This research method has been used in production [Al-Saleh, 2011], healthcare services [Lopetegui, Yen, Lai, Jeffries, Embi \& Payne, 2014], process of physical workers [Magu, Khanna \& Seetharaman, 2015], and to some extent, in managerial work [Tengblad, 2002, pp. 562-564].

These attempts of recording, firstly, physical work and, secondly, managerial work, had two disadvantages. Firstly, the periods between frames of work in $t_{1}$ and $t_{2}$ were too long to understand the essence of activities. Secondly, they we 
not universal to many fields of activities, but they were designed according to the certain aim of research. Nonetheless, these research attempts were an inspiration to solve the dilemma which research method to use in the research focused on managerial actions.

The solution of this problem is a long-term, non-participating observation of manager work with a short period of succeeding frames of work. The origin of this approach comes from movie making and it is presented in Figure 3.

Figure 3. Frames in a movie

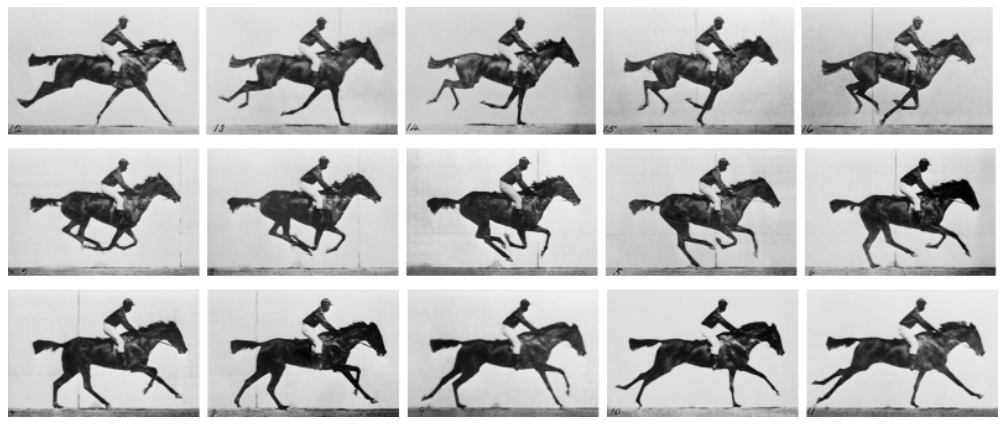

Source: http://www.historiasztuki.com.pl/

The long-term, non-participating observation of certain managerial action needs a special research tool which would let record the managerial action in time, content and human relations domains. This was the next problem to solve in a way to team management automation.

\section{RESEARCH TOOLS}

In the research of team management the most frequent research tool is a questionnaire of a survey or an interview [Flak, Yang \& Grzegorzek, 2017, p. 387]. In the perspective of a long-term, non-participating observation this tool is not sufficient to gather data on managerial actions. Firstly, questionnaires collect data mostly on opinions but not facts. Secondly, the frequency of framed managerial actions should be as high as it possible, respecting some technical limits, such as a capacity of a data base. Therefore there was a need to design a research tool similar to a camera used during movie making.

From the point of view of the long-term, non-participating observation of manager work there is an assumption based on the idea of an „unit of behaviour" [Curtis et al., 1992]. It is assumed that every research tool tracks and records one specific managerial action [as it is described in Section 2]. It was also decided that the most efficient way of gathering data on managerial actions is to design research tools which are in the same time management tools used by team manager or his team members during team work [Flak, 2013a]. 
As the most of time team managers spend working with online tools [Flak, 2008; Flak \& Hoffmann-Burdzińska, 2017], the management tools are nowadays most often online tools. The first research in this area [Flak, 2008] was the inspiration to design, implement and develop the idea of online management tools as research tools in the research platform called TransistorsHead (transistorshead. com, trial - team: manager, user: manager, password: manager). The dashboard of TransistorsHead is presented in Figure 4.

Figure 4. Dashboard of TransistorsHead

TransistorsHead
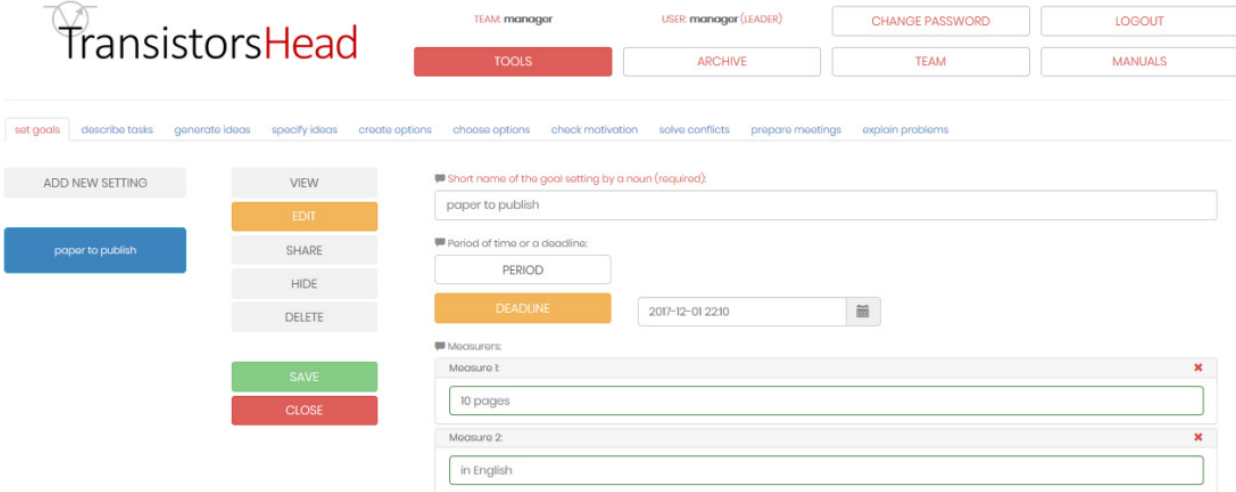

ADD NEW MEASURER

Source: Own elaboration

Figure 4 shows the dashboard of TransistorsHead with the example of the managerial action called SET GOALS (the name of the goal: ,paper to publish"). At the top there is a default TOOLS function. Other functions: administer members of their teams (TEAM), hide some created items [derivative organizational terms] into archive (ARCHIVE) and read instructions how to use the tools (MANUALS). Below there are 10 different tools for team management, e.g. set goals, describe tasks, specify ideas, create options, etc.

Every tool has ADD NEW button to create a new item, e.g. a new goal in SET GOALS. Below there is a list of items created, e.g. lists of goals in SET TOOLS. There are the same buttons for every tool (VIEW, EDIT, SHARE, DELETE, HIDE) and the confirmation area (SAVE, CLOSE). SAVE uploads the data base with new data about the item, e.g. new goal parameters in the SET GOALS, and it creates the representation of a particular managerial action. In the right vertical part there is an area for forms, buttons, text areas or combo lists which a manager uses to establish the content of the tool item, e.g. a goal's name, deadline and measures.

When a manager uses any online management tool it is equal to an event which effects in a thing, another words, equal to a process which results in 
a resource, respectively, as it is shown in the Figure 1 and Figure 2 [Flak, 2013c]. Every tool is useful for recording only one managerial action [Flak, 2013c].

The online management tools efficiently record managerial actions during team management which lets show how team managers and their team members work over time in given projects [Alnajjar \& Flak, 2016; Flak \& Hoffmann-Burdzińska, 2016a, Flak \& Hoffmann-Burdzińska, 2016b, Hoffmann-Burdzińska \& Flak, 2015]. However, there still is a question which method of reasoning to use in order to replace a human manager with a robot in some areas of team management.

\section{REASONING METHODS}

The aim of such data analysis should be launching automatic or semi-automatic managerial actions in team management. There were several attempts of using simple statistics [Flak, 2013b; Hoffmann-Burdzińska \& Flak, 2015], a linguistic analysis [Alnajjar \& Flak, 2016] and pattern recognition techniques [Flak, Yang \& Grzegorzek, 2017]. Nevertheless, this problem is still not fully solved. The most probable approach is using pattern recognition defined as a process that classifies the input data into object or classes based upon certain features extracted from sensory signals or other data about the objects. Its purpose is to characterize an object to be recognized by measurements whose values are very similar for objects in the same category, and very different for objects in different categories [Theodoridis \& Koutroumbas, 2008].

At present there is only a clear idea of a possibility how such an artificial manager could play a managerial role in team work.

Figure 5. Idea of replacing a human manager with a robot
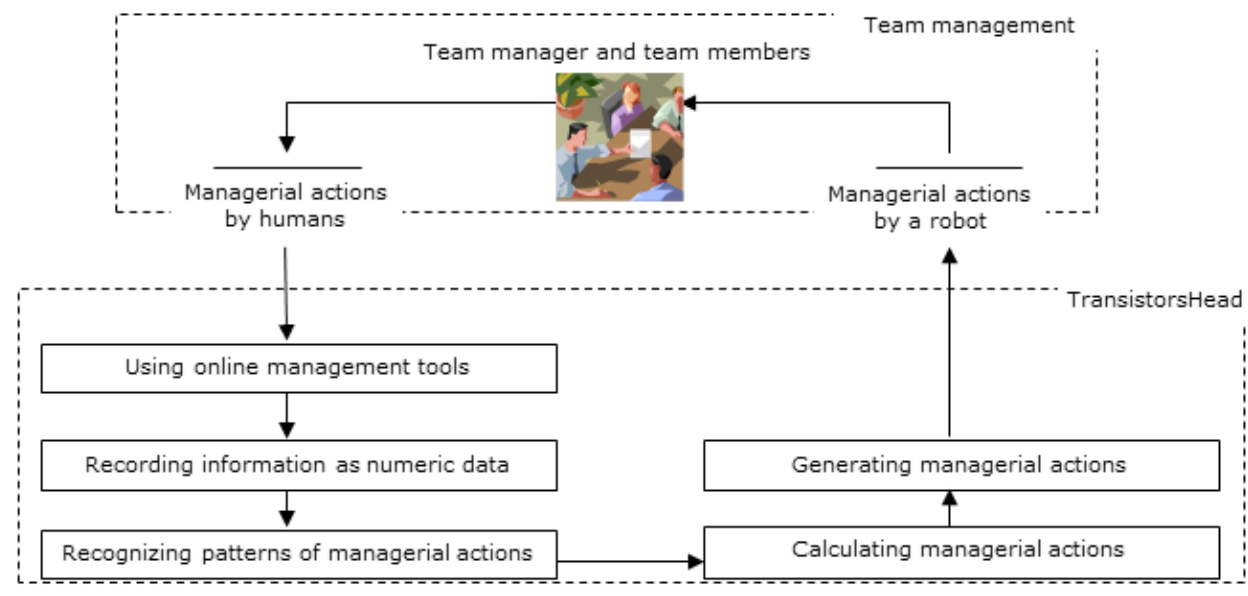

Source: Own elaboration 
As it is shown in Figure 5, the idea is so that the team manager and team members generate managerial actions which are recorded by the online management tools as numeric data in time, content and human relations domains. Then pattern recognition techniques let distinguish patterns of behavior in these three areas answering to questions what, who, when, how, where and with whom. On this background next managerial actions are calculated and generated by TransistorsHead when, e.g. a human team manager is away. These managerial actions are focused on team members as if they were created by a human manager.

\section{CONCLUSIONS}

The methodological area of replacing human managers with robots is not only field of problems. There is also an ethical dilemma which shows a robot as a powerful object in making human decision [Anderson \& Anderson, 2007; Beer, Fisk \& Rogers, 2014]. However, before solving this problem there is a strong need of solving the problems presented in the paper.

As it was presented in Sections above, most of them have stable and verified solutions, such as the system of organizational terms, which lets create a view of organizational reality with organizational terms. Primal and derivative organizational terms in team management create managerial actions which are sufficient representation of manager work. The long-term, non-participating observation method along with online management tools lets record data on managerial actions and draw conclusion what the team manager really makes. The next challenges are to distinguish some behavioural patterns of team managers and team members and then imitate them with artificial managerial actions. These problems are new research challenges in the management science [Scherbaum \& Meade, 2013].

\section{REFERENCES}

Alnajjar J. \& Flak O., (2016), A Managerial and Linguistic Perspective on Researching Manager Behaviour Aimed at Replacing Human Managers with Robots, "International Journal of Systems and Society", Vol. 3, No. 2, 14-29

Al-Saleh K.S., (2011), Productivity improvement of a motor vehicle inspection station using motion and time study techniques, "Journal of King Saud University - Engineering Sciences", No. 23, 33-41.

Anderson M. \& Anderson S.L, (2007), Machine Ethics: Creating an Ethical Intelligent Agent, AI Magazine, Vol. 28, No. 4, 15-26.

Barnes R.M., (1980), Motion and time study. Design and Measurement of Work, 7th ed., John Wiley, New York.

Barney J.B., (1991), Firm resources and sustained competitive advantage, "Journal of Management", Vol. 17, Issue 1, 99-120.

Beer J.M, Fisk A.D. \& Rogers W.A., (2014), Toward a Framework for Levels of Robot Autonomy in Human-Robot Interaction, "Journal of Human-Robot Interaction", Vol. 3, Issue 2, 74-99. 
Blake R.R. \& Mouton J.S., (1965), International Managerial Grids, "Training Directors Journal”, Vol. 19, Issue 5, 8-23, 1965.

Brajer-Marczak R., (2016), Elements of knowledge management in the improvement of business processes, "Management", Vol. 20, Issue 2, 242-260.

Darmer P., (2000), The subject(ivity) of management, "Journal of Organizational Change Management", Vol. 13, Issue 4, 334-351.

Drucker P.F., (1967), The Manager and the Moron, "McKinsey Quarterly", 12, http://www.mckinsey.com/business-functions/organization/our-insights/the-manager-and-the-moron

Flak O. \& Hoffmann K., (2017), Wpływ narzędzi menedżerskich online na pracę zespołu. Wyniki badań, [in:] Knosala R. (Ed.), Innowacje w zarządzaniu i inżynierii produkcji (pp 173-182), Oficyna Wydawnicza Polskiego Towarzystwa Zarządzania Produkcją, Opole.

Flak O. \& Hoffmann-Burdzińska K., (2016a), Management Techniques and Tools in Project Planning - Part 1. Quantitative Results Of Research [in:] Knosala R. (Ed.), Innovation in Management and Production Engineering (pp 277-287), Oficyna Wydawnicza Polskiego Towarzystwa Zarządzania Produkcją, Opole.

Flak O. \& Hoffmann-Burdzińska K., (2016b), Management Techniques and Tools in Project Planning - Part 2. Qualitative Results Of Research [in:] Knosala R. (Ed.), Innovation in Management and Production Engineering (pp 288-298), Oficyna Wydawnicza Polskiego Towarzystwa Zarządzania Produkcją, Opole.

Flak O., (2007), Układ wielkości organizacyjnych jako obiekt badań [in:] Nalepka A. (Ed.), Organizacje komercyjne i niekomercyjne wobec wzmożonej konkurencji oraz wzrastajacych wymagań konsumentów (pp 64-74), Wyższa Szkoła Biznesu, Nowy Sącz.

Flak O., (2008), Konceptualizacja układu wielkości organizacyjnych [in:] Nalepka A. (Ed.), Organizacje komercyjne i niekomercyjne wobec wzmożonej konkurencji oraz wzrastajacych wymagań konsumentów (pp 13-22), Nowy Sącz: Wyższa Szkoła Biznesu.

Flak O., (2008), Wptyw interaktywnych technik internetowych na zarzadzanie firma w przyszłości - wyniki badań [in:] Kiełtyka L. (Ed.), Technologie i systemy komunikacji oraz zarządzania informacja i wiedza (pp 58-68), Difin, Warszawa.

Flak O., (2009), Propozycja metody ustalania definicji w układzie wielkości organizacyjnych [in:] Nalepka A. (Ed.), Organizacje komercyjne i niekomercyjne wobec wzmożonej konkurencji oraz wzrastajacych wymagań konsumentów (pp 11-20), Nowy Sącz: Wyższa Szkoła Biznesu.

Flak O., (2010), Wymiary i wielkości mierzone w uktadzie wielkości organizacyjnych [in:] Nalepka A. (Ed.), Organizacje komercyjne i niekomercyjne wobec wzmożonej konkurencji oraz wzrastających wymagań konsumentów (pp. 11-21). Nowy Sącz: Wyższa Szkoła Biznesu.

Flak O., (2013a), Concept of managerial tools based on the system of organizational terms [in:] Knosala R. (Ed.), Innovation in Management and Production Engineering (pp 187-197), Oficyna Wydawnicza Polskiego Towarzystwa Zarządzania Produkcją, Opole.

Flak O., (2013b), Results of Observations of Managers Based on the System of Organizational Terms [in:] Nalepka A., Ujwary A. (Eds.), Business and Non-profit Organizations Fading Increased Competition and Growing Customers' Demands (pp 89-102), Wyższa Szkoła Biznesu, Nowy Sącz.

Flak O., (2013c), Theoretical foundation for managers'behavior analysis by graph-based pattern matching, "International Journal of Contemporary Management", Vol. 12 Issue 4, 110-123.

Flak O., Yang C. \& Grzegorzek M., (2017), Action Sequence Matching of Team Managers [in:] Proceedings of the 5th International Conference on Pattern Recognition Applications and Methods ICPRAM, 386-393.

Gleiser M., (2014), The island of knowledge: the limits of science and the search for meaning, Basic Books, New York. 
Herauf T.S., (2006), Metrics for Managers, "Journal of the Quality Assurance Institute", Vol. 20 Issue 4, 34-40.

Hicks H.G. \& Goronzy F., (1967), On methodology in the study of management and organization, "Academy of Management Journal", Vol. 10 Issue 4, 371-384.

Hodge R., (2003), Towards a postmodern science of language, "Social Semiotic", Vol. 13, Issue 3, 241-262.

Hoffmann-Burdzińska K. \& Flak O., (2015), Management by objectives as a method of measuring HR teams effectiveness, "Journal of Positive Management", Vol. 6, No. 3, 67-82.

Karsten L., (1996), Writing and the advent of scientific management: the case of time and motion studies, "Scandinavian Journal of Management", Vol. 12, Issue 1, 41-55.

Katz R.L., (1974), Skills of an effective administrator, "Harvard Business Review", Vol. 52, Issue 2, 90-102.

Koontz H., (1961), The management theory jungle, "The Journal of the Academy of Management", Vol. 4, Issue 3, 174-188.

Likert R., (1958), Measuring Organizational Performance, "Harvard Business Review", Vol. 36, Issue 2, 41-50.

Lopetegui M., Yen P-Y., Lai A., Jeffries J., Embi P. \& Payne P., (2014), Time motion studies in healthcare: What are we talking about?, "Journal of Biomedical Informatics", Vol. 49, 292-299.

Magu P., Khanna K. \& Seetharaman P., (2015), Path process chart - a technique for conducting time and motion study, "Procedia Manufacturing", Vol. 3, 6475-6482.

Mathieu J., Maynard M.T., Rapp T., \& Gilson L., (2008), Team effectiveness 1997-2007: A review of recent advancements and a glimpse into the future, "Journal of Management", Vol 34, Issue 3, 410-476.

McAfee A., Goldbloom A., Brynjolfsson E. \& Howard J., (2014), Artificial Intelligence meets the C-suite, "McKinsey Quarterly", 3rd Quarter (3), 66-75.

McAfee A., Goldbloom A., Brynjolfsson E. \& Howard J., (2014), Artificial Intelligence meets the C-suite, "McKinsey Quarterly", 3rd Quarter (3), 66-75.

Mintzberg H., (1980), The nature of managerial work, Prentice-Hall, New York.

Pavett C.M. \& Lau A.W., (1983), Managerial work: the influence of hierarchical level and functional specialty, "Academy of Management Journal", Vol. 26, Issue 1, 170-177.

Rios D., (2013), Models and modeling in the social sciences, "Perspectives on Science", Vol. 21, Issue 2, 221-225.

Rokita J., (2010), Systemowe podejście do badań nad zachowaniami organizacji [in:] Jagoda H., Lichtarski J. (Eds.), Kierunki i dylematy rozwoju nauki i praktyki zarządzania przedsiębiorstwem (pp. 258-262). Wydawnictwo UE we Wrocławiu, Wrocław.

Scherbaum C.A. \& Meade A.W., (2013), New Directions for Measurement in Management Research, "International Journal of Management Reviews", Vol. 15, 132-148.

Segal S., (2011), A Heideggerian perspective on the relationship between Mintzberg's distinction between engaged and disconnected management: the role of uncertainty in management, "Journal of Business Ethics", Vol. 103, Issue 3, 469-483.

Sinar E. \& Paese M., (2016), The new leader profile, "Training Magazine”, Vol. 46, 46-50.

Spriegel W.R. \& Myers C.E., (1953), The writings of the Gilbrerhs. Homewood, Chicago.

Sudoł S., (2010), Main Dilemmas of Management Science, "Organization and Management", No 1 (139), 8-9.

Sułkowski Ł., (2004), Problem niewspótmierności koncepcji w zarządzaniu, „Przegląd Organizacji”, $\mathrm{Nr}$ 4, 6-8. 
Tannenbaum R. \& Schmidt W.H., (1958), How to choose a leadership pattern, "Harvard Business Review", Vol. 36, Issue 2, 95-101.

Tengblad S., (2002), Time and space in managerial work, "Scandinavian Journal of Management", Vol. 18, Issue 4, 543-565.

Theodoridis S. \& Koutroumbas K., (2008), Pattern Recognition, Academic Press, Cambrigde.

Zalabardo J., (2015), Representation and reality in Wittgenstein's Tractatus. Oxford University Press, Oxford.

http://www.historiasztuki.com.pl/strony/015-00-01-FILM-TECHNIKA.html [23.11.2017].

\section{WYBRANE PROBLEMY AUTOMATYZACJI ZARZĄDZANIA ZESPOŁEM}

Z a r y s t r e ś c i: Z jednej strony natura pracy zespołowej jest bardzo złożona i w swojej strukturze niestabilna. $Z$ drugiej strony nowoczesne technologie informatyczne dają możliwość automatyzacji wielu obszarów życia codziennego. Powstaje zatem pytanie, w jaki sposób zastąpić menedżera zespołu robotem. W artykule zaprezentowane wybrane problemy w tym zakresie, a w szczególności wynikające $\mathrm{z}$ istniejących problemów metodologicznych nauk o zarządzaniu, różnorodnych prób reprezentacji pracy menedżera, dylemat wyboru metody badawczej oraz narzędzi badawczych, które pozwoliłyby zgromadzić wiedzę na temat tego, jakie czynności wykonuje menedżer, a także jakie metody wnioskowania zastosować w celu imitacji menedżera-człowieka. Niektóre z tych problemów zostały już przez autora rozwiązane, ale pozostałe wciąż oczekują na rozwiązanie.

S ł o w a k l u c z o w e: metodologia nauk o zarządzaniu, układ wielkości organizacyjnych, metoda badawcza, narzędzie badawcze, narzędzie menedżerskie online, automatyzacja pracy menedżera 